\title{
Zaluzanin C Inhibits Differentiation of 3T3-L1 Preadipocytes into Mature Adipocytes
}

\author{
Sang Hee Kwak' ${ }^{1}$ Yoon Hee Kim ${ }^{1,2,3, *}$ \\ ${ }^{1}$ Department of Food and Nutrition, ${ }^{2}$ Research Institute of Anti-Aging, and ${ }^{3}$ Institute of Industrial and Technology, Daegu University, Gyeongsan, Korea
}

Background: An excess storage of body fat causes obesity. Since obesity increases risk of chronic diseases, it is important to inhibit excessive storage of fat. Zaluzanin $C$ is a sesquiterpene lactone isolated from Ainsliaea acerifolia. The aim of this study was to demonstrate the effect of zaluzanin C on differentiation of 3T3-L1 preadipocytes into mature adipocytes.

Methods: The cytotoxicity of zaluzanin C and its effect on cell proliferation was determined. For the induction of adipocyte differentiation, 3T3-L1 preadipocytes were treated with differentiating medium containing $10 \mu \mathrm{g} / \mathrm{mL}$ insulin, $115 \mu \mathrm{g} / \mathrm{mL}$ methylisobutylxanthine, and $1 \mu \mathrm{M}$ dexamethasone. Differentiated 3T3-L1 cells were subjected to Oil red $\mathrm{O}$ solution or used for Western blot analysis. Zaluzanin $\mathrm{C}$ was added to the cell culture medium at concentrations of $0,1,2.5,5$, and $10 \mu \mathrm{M}$.

Results: Zaluzanin C did not inhibit cell proliferation and showed no cytotoxicity at $10 \mu \mathrm{M}$ concentration in 3T3L1 cells. Therefore, concentration range of 0-10 $\mu \mathrm{M}$ zaluzanin $\mathrm{C}$ was used for subsequent experiments. Zaluzanin C inhibited accumulation of lipid droplets in 3T3-L1 adipocytes. To understand the underlying mechanism of zaluzanin C, expression of adipogenesis regulators was determined by Western blot analysis. Zaluzanin C suppressed peroxisome proliferator-activated receptor gamma (PPAR $\gamma$ ) expression, an adipogenesis related transcription factor, and inhibited aP2/fatty acid-binding protein-4 expression, a target gene of PPAR $\gamma$. However, it did not affect expression of CCAAT/enhancer-binding protein alpha related with acquisition of insulin sensitivity. Conclusion: These data suggest that inhibitory effect of zaluzanin C on adipogenesis of 3T3-L1 adipocytes could be partially caused by suppressing PPAR $\gamma$.

Key words: Zaluzanin C, Lactone, 3T3-L1 cell, Proliferator-activated receptor gamma
Received March 9, 2019

Reviewed April 11, 2019

Accepted June 19, 2019

\section{${ }^{*}$ Corresponding author}

Yoon Hee Kim

\section{(iD)}

https://orcid.org/0000-0003-2914-1280

Department of Food and Nutrition, Daegu University, 201 Daegudae-ro, Jillyang-eup, Gyeongsan 38453, Korea Tel: +82-53-850-6834 Fax: +82-53-850-6839 E-mail: kimyh0128@daegu.ac.kr

\section{INTRODUCTION}

Prevalence rate of obesity has increased since 1988. Particularly, it was $42.3 \%$ among males in South Korea in $2016 .{ }^{1}$ Obesity is a significant risk factor for many serious illnesses such as gastrointestinal cancer, heart disease, stroke and diabetes. ${ }^{2-5}$ Increased physical activity, diet modification, drugs, and surgery are common strategies to treat obesity. ${ }^{6}$ Currently available anti-obesity drugs are associated with several adverse effects such as hyperthyroidism, palpitations, anxiety, insomnia, and diarrhea. ${ }^{7}$ Therefore, there is a growing demand for the development of new and safe anti-obesity agents.

Imbalance between energy intake and its consumption can lead to an excessive accumulation of lipids in the adipose tissue. Adipose tissue is a key regulator of energy balance, playing an active role in lipid storage and buffering, synthesizing, and secreting a wide range of endocrine products into blood circulation that influence systemic metabolism. ${ }^{8}$ Therefore, inhibition of adipogenesis in adipocytes could be a good strategy to prevent and treat obesity.

Ainsliaea acerifolia is a perennial plant, which belongs to the family Compositae and has been used in folk medicine for the treatment of rheumatoid arthritis and enteritis. ${ }^{9}$ It has been reported 
that zaluzanin C, a sesquiterpene lactone mainly isolated from family Compositae, exhibits anti-fungal, anti-inflammatory and anticancer activities, and osteoblastic differentiation potential. ${ }^{10-17}$ However, its effect on differentiation of 3T3-L1 preadipocytes remains uncertain. Therefore, this study aimed to investigate whether zaluzanin C affects the differentiation of 3T3-L1 preadipocytes into mature adipocytes.

\section{METHODS}

\section{Reagents}

For cell culture, bovine calf serum (BCS), fetal bovine serum (FBS), penicillin, streptomycin, Dulbecco's modified Eagle's medium (DMEM) and 0.5\% Trypsin-ethylenediaminetetraacetic acid (EDTA) were purchased from Hyclone (Logan, UT, USA). Methylisobutylxanthine (IBMX), dexamethasone, insulin, and Oil red O solution were obtained from Sigma-Aldrich (St. Louis, MO, USA). Sodium pyruvate was purchased from Gibco Invitrogen (Carlsbad, CA, USA). Formaldehyde solution was obtained from Junsei chemical (Tokyo, Japan). For protein estimation, Bio-Rad Protein Assay kit was purchased from Bio-Rad Laboratories (Hercules, CA, USA). Anti-aP2/fatty acid binding protein 4 (FABP4) rabbit polyclonal (\#2120) and anti-CCAAT/enhancer binding protein alpha (C/EBP $\alpha$; D56F10, \#8178) antibodies were procured from Cell Signaling Technology (Danvers, MA, USA), and anti-peroxisome proliferator-activated receptor gamma (PPAR $\gamma$; E-8, \#sc-7273) and anti- $\beta$-actin mouse monoclonal antibodies were purchased from Santa Cruz Biotechnology (Dallas, TX, USA) and Novus Biologicals (Littleton, CO, USA), respectively.

\section{Isolation of zaluzanin $\mathrm{C}$}

Zaluzanin $\mathrm{C}$ was extracted and isolated from Ainsliaea acerifolia using a method developed by Lee et al..$^{18} A$. acerifolia was purchased from Yeongyang-gun, Gyeongsangbuk-do, Korea in May 2013. A. acerifolia $(5.0 \mathrm{~kg})$ was extracted with $70 \%$ ethanol $(\mathrm{EtOH})$ at room temperature and the solvent was evaporated in vacuo. The crude $\mathrm{EtOH}$ extract was suspended in distilled water (DW), and then partitioned in turn with $n$-hexane, ethyl acetate (EtOAc) and $n$-butyl alcohol $(n-\mathrm{BuOH})$ to yield after concentration dried $n$-hexane (73.8 g), EtOAc (56.0 g), n-BuOH (27.9 g) and $\mathrm{H}_{2} \mathrm{O}$-soluble
$(186.0 \mathrm{~g})$ residues. A portion $(20.0 \mathrm{~g})$ of the EtOAC-soluble fraction was chromatographed over a Toyopearl HW 40 (coarse grade; $1.5 \mathrm{~cm} \times 51 \mathrm{~cm}$ ) with $\mathrm{H}_{2} \mathrm{O}$ containing increased amounts of methanol $(\mathrm{MeOH})$ in a stepwise gradient mode. The $\mathrm{H}_{2} \mathrm{O}$ eluate was subjected to a combination of chromatography over YMC gel ODS AQ $120 \mathrm{~S}$ column $(1.1 \mathrm{~cm} \times 40 \mathrm{~cm})$ with aqueous $\mathrm{MeOH}$ to yield pure zaluzanin $\mathrm{C}(188.4 \mathrm{mg})$.

\section{Cell line and culture}

3T3-L1 mouse embryonic fibroblast cell line is derived from 3T3 cells and is widely used in biological research on adipose tissue. ${ }^{19}$ 3T3-L1 cell line was obtained from the Korean Cell Bank (Seoul, Korea), and was grown in DMEM supplemented with $10 \%$ BCS, $100 \mathrm{U} / \mathrm{mL}$ penicillin and $100 \mu \mathrm{g} / \mathrm{mL}$ streptomycin. Cells were maintained at $37^{\circ} \mathrm{C}$ in a humidified incubator with $5 \% \mathrm{CO}_{2}$.

\section{Cell differentiation}

For the induction of adipocyte differentiation, 3T3-L1 preadipocytes were seeded at a density of $5 \times 10^{4}$ cells $/ \mathrm{mL} /$ well in a 24-well plate. As shown in Fig. 1, at confluence (day 0), the cultured preadipocytes were induced to differentiate by the addition of differentiating medium (DMEM containing $115 \mu \mathrm{g} / \mathrm{mL}$ IBMX, $10 \mu \mathrm{g} / \mathrm{mL}$ insulin, and $1 \mu \mathrm{M}$ dexamethasone) from day 0 to day 6. At day 6 , medium was changed with medium containing $10 \mu \mathrm{g} / \mathrm{mL}$ insulin for an additional 6 days from day 6 to day 12. The medium was refreshed every 3 days. At day 12, differentiated 3T3-L1 cells were subjected to Oil red O solution or used for Western blot analysis. Zaluzanin $\mathrm{C}$ was dissolved in dimethyl sulfoxide (DMSO) and was added to the cell culture medium at concentrations of $0,1,2.5,5$, and $10 \mu \mathrm{M}$ from day 0 to day 12 (Fig. 1). Light microscopy and Oil red $\mathrm{O}$ staining were used to monitor the characteristic cell rounding and lipid accumulation during the cell differentiation, respectively.

\section{Oil red 0 staining}

After cell differentiation, cells were fixed with $1 \mathrm{~mL}$ of $10 \%$ formaldehyde solution for 1 hour. Fixed cells were washed with $2 \mathrm{~mL}$ of $60 \%$ isopropyl alcohol and were air dried. One milliliter of Oil red O solution was added to each well and the each well was incubated for 10 minutes. After the removal of Oil red O solution, cells were 


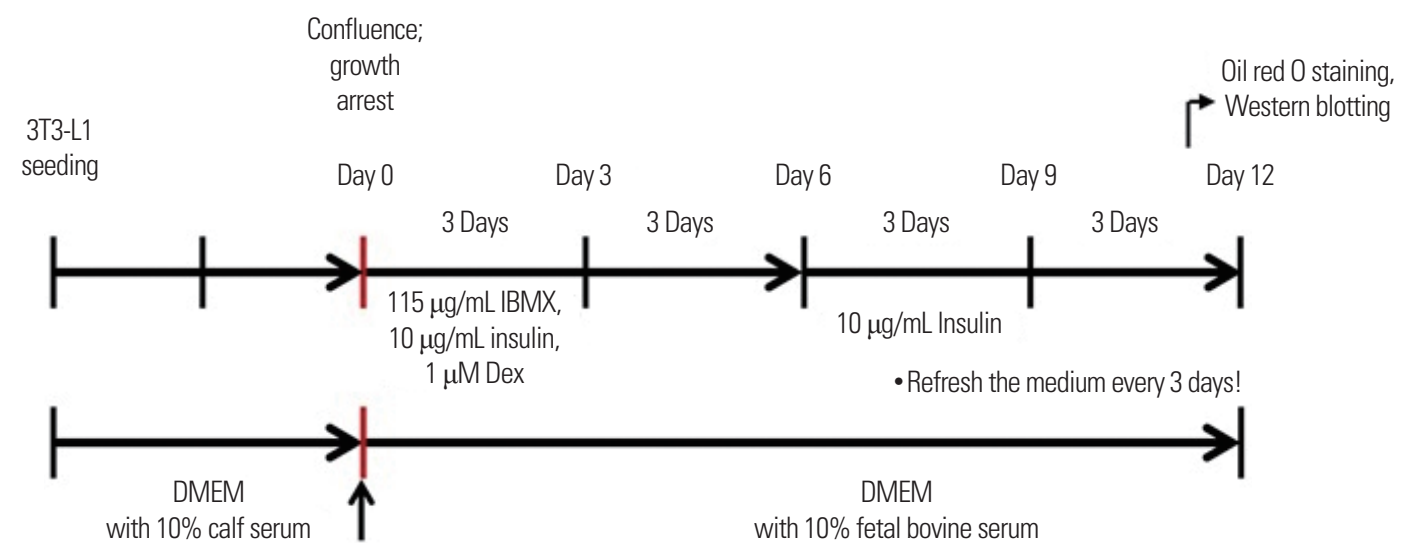

Zaluzamin C

$(0,1,2.5,5,10 \mu \mathrm{M})$

Figure 1. Experimental scheme. For the induction of adipocyte differentiation, 3T3-L1 preadipocytes were seeded. At confluence (day 0), the cultured preadipocytes were induced to differentiate by the addition of differentiating medium containing $115 \mu \mathrm{g} / \mathrm{mL}$ methylisobutylxanthine (IBMX), $10 \mu \mathrm{g} / \mathrm{mL}$ insulin, and $1 \mu \mathrm{M}$ dexamethasone (Dex) from day 0 to day 6 . At day 6 , medium was changed with medium containing $10 \mu \mathrm{g} / \mathrm{mL}$ insulin for an additional 6 days from day 6 to day 12 . The medium was refreshed every 3 days. At day 12, differentiated 3T3-L1 cells were subjected to Oil red 0 solution or used for Western blot analysis. Zaluzanin C was added to the cell culture medium at concentrations of $0,1,2.5,5$, and $10 \mu \mathrm{M}$ from day 0 to day 12 . DMEM, Dulbecco's modified Eagle's medium.

washed four times with DW and imaged. Accumulated intracellular Oil red $\mathrm{O}$ dye was completely extracted by $1 \mathrm{~mL}$ of $100 \%$ isopropyl alcohol and quantified by measuring its absorbance at $490 \mathrm{~nm}$ (Sunrise Tecan, Grödig, Austria).

\section{Cell proliferation and cytotoxicity assay}

The cytotoxicity of zaluzanin $\mathrm{C}$ and its effect on cell proliferation was determined using CytoTox96 Non-Radioactive Cytotoxicity Assay (Promega, Madison, WI, USA) and CellTiter96 Aqueous One Solution Assay of cell proliferation (Promega), respectively. 3T3-L1 preadipocytes were seeded at a density of $1 \times 10^{4}$ cells/ $200 \mu \mathrm{L} /$ well in a 96 well plate, and zaluzanin $\mathrm{C}$ was added to each well at a concentration range of $0-10 \mu \mathrm{M}$ in DMEM containing $1 \%$ FBS. After 48-hour incubation, cytotoxicity and cell proliferation were measured according to the manufacturer's instructions. In $0 \mu \mathrm{M}$ zaluzanin $\mathrm{C}$ group, cells were treated with an equal volume of DMSO, maintained at maximum concentration of not more than $0.001 \% \mathrm{v} / \mathrm{v}$.

\section{Preparation of whole cell lysates}

To prepare whole cell lysate, cells were lysed in lysis buffer containing $50 \mathrm{mM}$ Tris- $\mathrm{HCl}$ (pH 7.5), $150 \mathrm{mM} \mathrm{NaCl,} \mathrm{1 \%} \mathrm{Triton}$ $\mathrm{X}-100,1 \mathrm{mM}$ EDTA, $50 \mathrm{mM}$ sodium fluoride (NaF), $30 \mathrm{mM}$ sodium pyrophosphate $\left(\mathrm{Na}_{4} \mathrm{P}_{2} \mathrm{O}_{7}\right), 1 \mathrm{mM}$ phenylmethanesulfonyl fluoride, $2 \mathrm{mg} / \mathrm{mL}$ aprotinin, and $1 \mathrm{mM}$ pervanadate. The lysates were clarified by centrifugation at $12,000 \times g$ for 15 minutes at $4^{\circ} \mathrm{C}$. The lysates were stored at $-80^{\circ} \mathrm{C}$ until needed.

\section{Western blotting analysis}

Proteins in whole cell lysates were separated by $10 \%$ sodium dodecyl sulfate-polyacrylamide gel electrophoresis (SDS-PAGE) and were transferred to Immobilon transfer membranes with pore size of $0.45 \mu \mathrm{m}$ (Millipore, Billerica, MA, USA). After blocking with $1 \times$ blocking buffer (Biofact Biofactory, Daejeon, Korea) for 1 hour, membranes were incubated with the primary antibody at $4^{\circ} \mathrm{C}$ overnight. Membranes were then washed with Tris buffered salineTween 20 solution and were incubated with anti-rabbit or antimouse immunoglobulin $\mathrm{G}$ conjugated to horseradish peroxidase for 1 hour. After washing, the protein bands were then visualized using enhanced chemiluminescence reagent (Thermo Fisher Scientific Inc., Pittsburgh, PA, USA) and LAS-3000 Lumino Image Analyzer System (Fujifilm, Tokyo, Japan). Densitometric measurements of band intensities were performed using Image J free software (NIH, Bethesda, MA, USA).

\section{Statistical analysis}

GraphPad Prism version 5.0 software (GraphPad, San Diego, CA, USA) was used for statistical analysis. The data were expressed 
A

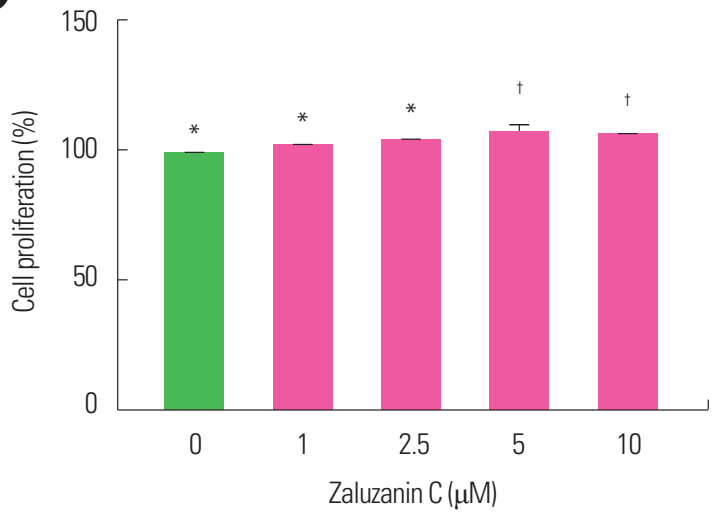

B

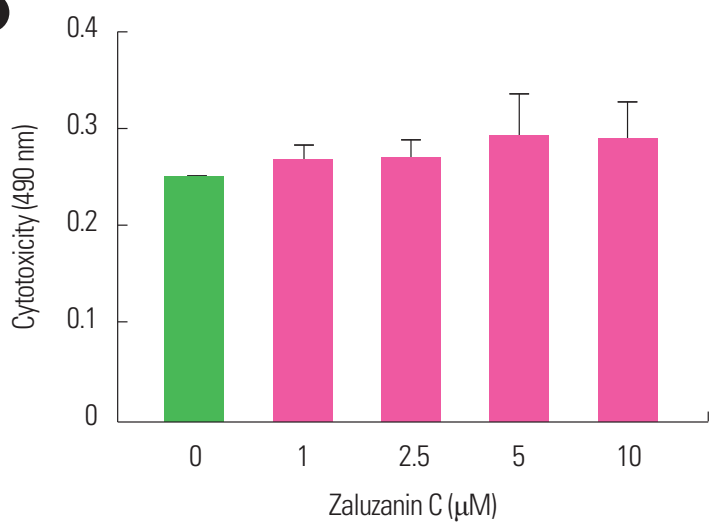

Figure 2. Effect of zaluzanin C on cell proliferation and cytotoxicity in 3T3-L1 preadipocyte. 3T3-L1 cells were seeded in a 96 well plate and treated with various concentrations of zaluzanin $\mathrm{C}(0,1,2.5,5$, and $10 \mu \mathrm{M})$. After 48 hours, cell proliferation $(\mathrm{A})$ and cytotoxicity (B) were determined using CytoTox 96 non-radioactive cytotoxicity assay and CellTiter 96 Aqueous One Solution assay. The results are presented as mean \pm standard error of the mean of three independent experiments $(\mathrm{n}=3)$. *, ${ }^{*} \mid n d i c a t e ~ s t a t i s t i-$ cally significant differences between groups.

as the mean \pm standard error of the mean of three independent experiments. Differences between the mean values of multiple groups were analyzed using one-way analysis of variance with Dunnett test or Tukey's test. A $P<0.05$ was considered as statistically significant.

\section{RESULTS}

As part of our ongoing screening program, antiadipogenic potentials of 11 types of bioactive compounds were evaluated. ${ }^{20}$ According to Kwak's study ${ }^{20}, 10 \mu \mathrm{M}$ zaluzanin C inhibited lipid accumulation, a characteristic of differentiated adipocytes ${ }^{21,22}$, in 3T3-L1 adipocytes. Based on this result, antiadipogenic potential of zaluzanin $\mathrm{C}$ and its underlying mechanism was evaluated in the subsequent experiments.

As $10 \mu \mathrm{M}$ zaluzanin $\mathrm{C}$ was shown to inhibit lipid accumulation in 3T3-L1 adipocytes, its effect was examined on cell proliferation and cytotoxicity in 3T3-L1 preadipocytes. Since zaluzanin C did not inhibit cell proliferation and showed no cytotoxicity up to 10 $\mu \mathrm{M}$ concentration (Fig. 2), it was indicated that its inhibitory effect against lipid accumulation was not related to its cytotoxicity or antiproliferative effect. Therefore, zaluzanin $\mathrm{C}$ was used at a concentration range of $0-10 \mu \mathrm{M}$ for the subsequent experiments.

To evaluate the effect of zaluzanin $\mathrm{C}$ on lipid accumulation during adipogenesis of 3T3-L1 preadipocytes, intracellular lipid content was measured at day 12 using Oil red $\mathrm{O}$ staining. The absorbance value of the negative control was 0.04 and that of $0 \mu \mathrm{M}$ zalu-
A

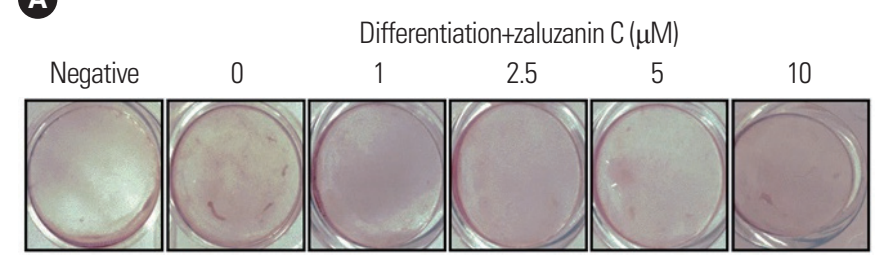

B

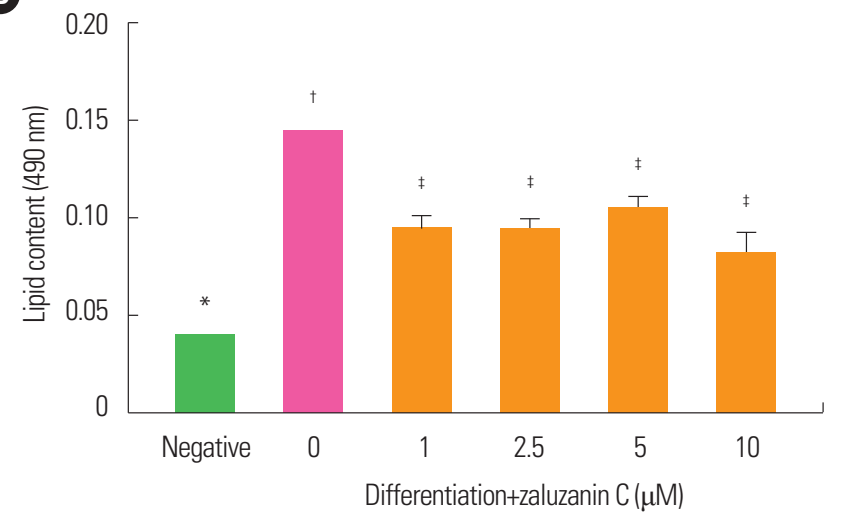

Figure 3. Effect of zaluzanin C on lipid accumulation in 3T3-L1 cells. 3T3-L1 cells were treated with differentiation medium in the absence or presence of different concentrations of zaluzanin $\mathrm{C}(0,1,2.5,5$, and $10 \mu \mathrm{M})$ for 12 days. (A) On day 12 , 3T3-L1 cells were stained with Oil-red 0 solution and took a photograph. (B) Lipid accumulation was then assessed by extracting Oil-red 0 from stained 3T3-L1 cells. The results are presented as mean \pm standard error of the mean of three independent experiments $(n=3) .{ }^{*,+,}$ Indicate statistically significant differences between groups.

zanin C was 0.14 (Fig. 3). Differentiation medium induced an increase in absorbance up to $350 \%$ in cells treated with $0 \mu \mathrm{M}$ zaluzanin C compared to the negative control group (Fig. 3).

An understanding of the process of adipose formation and the 

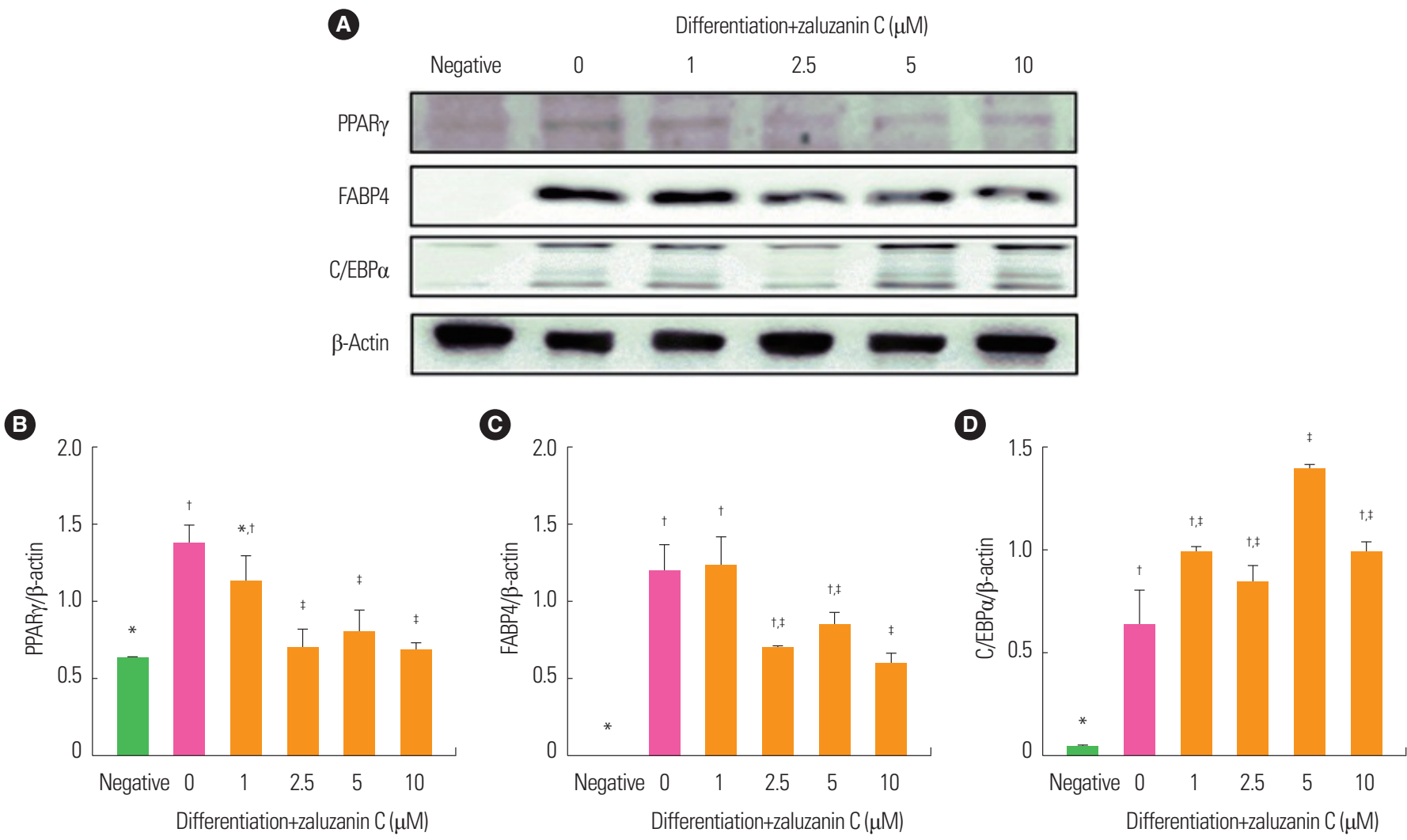

Figure 4. Effect of zaluzanin $\mathrm{C}$ on the expression of peroxisome proliferator-activated receptor gamma (PPAR $\gamma$ ), fatty acid binding protein 4 (FABP4) and CCAAT/enhancer binding protein alpha (C/EBP $\alpha$ ) in 3T3-L1 cells. 3T3-L1 cells were treated with differentiation medium in the absence or presence of different concentrations of zaluzanin $\mathrm{C}$ $(0,1,2.5,5,10 \mu \mathrm{M})$ for 12 days. From each whole cell lysate, $10 \mu \mathrm{g}$ of proteins was resolved by $10 \%$ sodium dodecyl sulfate-polyacrylamide gel electrophoresis for determination of FABP4, PPAR $\gamma$ and C/EBP $\alpha$ expression. $\beta$-actin expression is shown as a loading control. The bands $(\mathrm{A})$ were quantified using image analysis software, and their relative intensities of PPAR $(\mathrm{B}), \mathrm{FABP} 4(\mathrm{C})$, or $\mathrm{C} / \mathrm{EBP} \alpha(\mathrm{D})$ were expressed as target protein/ $\beta$-actin. The results are presented as mean \pm standard error of the mean of three independent experiments $(\mathrm{n}=3)$. $^{*,+t}$ Indicate statistically significant differences between groups.

mechanisms that govern adipogenesis is vital in the fight against the growing incidence of obesity. ${ }^{23}$ Therefore, attenuation of the expression of adipogenic related transcription factors, such as $\operatorname{PPAR} \gamma$ and $\mathrm{C} / \mathrm{EBP} \alpha$ by zaluzanin $\mathrm{C}$ was evaluated using Western blot analysis. At day 12, PPAR $\gamma$ expression was significantly increased in $0 \mu \mathrm{M}$ zaluzanin group compared to the negative control group (Fig. 4). Zaluzanin C effectively inhibited the differentiation medium-induced increase of PPAR $\gamma$ expression in 3T3-L1 adipocytes at concentrations greater than $1 \mu \mathrm{M}$. Then, expression of FABP4 protein was determined by Western blot analysis. Similarly, expression of FABP4 was decreased by treatment with zaluzanin C, significantly at $10 \mu \mathrm{M}$ concentration compared to $0 \mu \mathrm{M}$ zaluzanin $\mathrm{C}$ group. Also $\mathrm{C} / \mathrm{EBP} \alpha$ protein expression was significantly induced in $0 \mu \mathrm{M}$ zaluzanin $\mathrm{C}$ group compared to negative control cells. However, zaluzanin $\mathrm{C}$ did not inhibit expression of $\mathrm{C} / \mathrm{EBP} \alpha$.

\section{DISCUSSION}

Recently, many studies have been conducted in order to find natural bioactive agents which have antiadipogenic effect in 3T3-L1 preadipocytes. ${ }^{6,723,24}$ Immortalized murine cell lines such as 3T3$\mathrm{L} 1$ preadipocytes are capable of differentiating into mature white adipocytes under appropriate hormonal balance, in presence of FBS, dexamethasone, IBMX, and insulin. ${ }^{22,25}$ Since 3T3-L1 preadipocyte cell line as an in vitro model of adipogenesis has been proven to be an invaluable resource in elucidating mechanisms of adipocyte differentiation ${ }^{25}$, these cells were used to investigate the effects of zaluzanin $C$ on adipogenesis. From results of Fig. 3, they indicate that 3T3-L1 preadipocytes differentiate well into mature adipocytes by treatment with differentiation medium. However, treatment with $\geq 1 \mu \mathrm{M}$ zaluzanin $\mathrm{C}$ inhibited lipid accumulation in 3T3-L1 adipocytes. These results suggest that zaluzanin $\mathrm{C}$ has an 
antiadipogenic effect.

Adipogenesis is the process by which precursor stem cell differentiate into lipid laden adipocytes. ${ }^{21}$ This process is regulated by transcriptional activators such as PPAR $\gamma$ and C/EBP.$^{25,26}$ These transcription factors were known to regulate the middle and late stages of adipocyte differentiation. ${ }^{27}$ Also, FABP4 is a differentiated adipocyte marker gene that is transcriptionally regulated by $\operatorname{PPAR} \gamma{ }^{28,29}$ Although C/EBP $\alpha$ is an important factor in terminal differentiation of adipocytes, knockout of $\mathrm{C} / \mathrm{EBP} \alpha$ in adipocytes did not show insulin sensitivity. ${ }^{30,31}$ It means that $\mathrm{C} / \mathrm{EBP} \alpha$ is an essential factor in which adipocyte acquires insulin sensitivity. As obesity and insulin resistance are strongly linked to the accumulation of excessive lipids ${ }^{32}$, maintenance of C/EBP $\alpha$ by treatment of zaluzanin $\mathrm{C}$ has significant meaning in improving insulin resistance that occur by excess lipid accumulation. PPAR $\gamma$ is capable of promoting adipogenesis in $\mathrm{C} / \mathrm{EBP} \alpha$-deficient cells, whereas $\mathrm{C} / \mathrm{EBP} \alpha$ is incapable of promoting adipogenesis in PPAR $\gamma$-deficient cells. These findings demonstrate that PPAR $\gamma$ is a more important master regulator of adipogenesis than $\mathrm{C} / \mathrm{EBP} \alpha^{30}$

This is the first study to demonstrate that zaluzanin $\mathrm{C}$ inhibits differentiation of preadipocytes to mature adipocytes. These data suggest that zaluzanin C particularly affects PPAR $\gamma$, a key transcription factor for adipogenesis, and does not inhibit the process which acquires insulin sensitivity. Although this study does not reveal how zaluzanin $\mathrm{C}$ selectively regulate expression of $\mathrm{PPAR} \gamma$ and $\mathrm{C} / \mathrm{EBP} \alpha$, previous studies have demonstrated that zaluzanin $\mathrm{C}$ exhibited the most potent inhibitory effect in advanced glycation end products, which is valuable therapeutic targets for the regulation of diabetic complications. ${ }^{33}$ Also, zaluzanin C inhibited $\alpha$-glucosidase activity which is one of the targets for treatment of diabetes. ${ }^{18}$ As C/EBP $\alpha$ is an essential factor in which adipocytes acquire insulin sensitivity, maintenance of $\mathrm{C} / \mathrm{EBP} \alpha$ by treatment of zaluzanin $\mathrm{C}$ could positively affect improvement of obesity related diabetes. However, further study is needed to evaluate molecular mechanisms on how zaluzanin $\mathrm{C}$ increase expression of $\mathrm{C} / \mathrm{EBP} \alpha$. In conclusion, zaluzanin $\mathrm{C}$ may be a potential source for the treatment of obesity.

\section{CONFLICTS OF INTEREST}

The authors declare no conflict of interest.

\section{ACKNOWLEDGMENTS}

This work was supported and funded by Daegu University (No. 20160438).

\section{REFERENCES}

1. Ministry of Health and Welfare; Korea Centers for Disease Control and Prevention. Korea Health Statistics 2016: Korea National Health and Nutrition Examination Survey (KNHANES VII-1). Cheongju: Korea Centers for Disease Control and Prevention; 2016.

2. Murphy N, Jenab M, Gunter MJ. Adiposity and gastrointestinal cancers: epidemiology, mechanisms and future directions. Nat Rev Gastroenterol Hepatol 2018;15:659-70.

3. Piché ME, Poirier P, Lemieux I, Després JP. Overview of epidemiology and contribution of obesity and body fat distribution to cardiovascular disease: an update. Prog Cardiovasc Dis 2018;61:103-13.

4. Reho JJ, Rahmouni K. Oxidative and inflammatory signals in obesity-associated vascular abnormalities. Clin Sci (Lond) 2017; 131:1689-700.

5. Chukir T, Shukla AP, Saunders KH, Aronne LJ. Pharmacotherapy for obesity in individuals with type 2 diabetes. Expert Opin Pharmacother 2018;19:223-31.

6. Tung YC, Hsieh PH, Pan MH, Ho CT. Cellular models for the evaluation of the antiobesity effect of selected phytochemicals from food and herbs. J Food Drug Anal 2017;25:100-10.

7. Khalilpourfarshbafi M, Gholami K, Murugan DD, Abdul Sat$\operatorname{tar}$ MZ, Abdullah NA. Differential effects of dietary flavonoids on adipogenesis. Eur J Nutr 2019;58:5-25.

8. Romacho T, Elsen M, Röhrborn D, Eckel J. Adipose tissue and its role in organ crosstalk. Acta Physiol (Oxf) 2014;210: 733-53.

9. Jung CM, Kwon HC, Choi SZ, Lee JH, Lee DJ, Ryu SN, et al. Phytochemical constituents of Ainsliaea acerifolia. Korean J Pharmacogn 2000;31:125-9.

10. Wedge DE, Galindo JC, Macías FA. Fungicidal activity of natural and synthetic sesquiterpene lactone analogs. Phytochemistry 2000;53:747-57. 
11. Matsuda H, Kagerura T, Toguchida I, Ueda H, Morikawa T, Yoshikawa M. Inhibitory effects of sesquiterpenes from bay leaf on nitric oxide production in lipopolysaccharide-activated macrophages: structure requirement and role of heat shock protein induction. Life Sci 2000;66:2151-7.

12. Shin SG, Kang JK, Lee KR, Lee HW, Han JW, Choi WS. Suppression of inducible nitric oxide synthase and cyclooxygenase-2 expression in RAW 264.7 macrophages by sesquiterpene lactones. J Toxicol Environ Health A 2005;68:2119-31.

13. Kang YR, Lee HW, Kim YH. Anti-inflammatory effect of Zaluzanin $\mathrm{C}$ on lipopolysaccharide-stimulated murine macrophages. Korean J Food Sci Technol 2016;48:392-7.

14. Lajter I, Pan SP, Nikles S, Ortmann S, Vasas A, Csupor-Löffler $\mathrm{B}$, et al. Inhibition of COX-2 and NF-kB1 gene expression, NO production, 5-LOX, and COX-1 and COX-2 enzymes by extracts and constituents of Onopordum acanthium. Planta Med 2015;81:1270-6.

15. Choi SZ, Yang MC, Choi SU, Lee KR. Cytotoxic terpenes and lignans from the roots of Ainsliaea acerifolia. Arch Pharm Res 2006;29:203-8.

16. Csupor-Löffler B, Zupkó I, Molnár J, Forgo P, Hohmann J. Bioactivity-guided isolation of antiproliferative compounds from the roots of Onopordum acanthium. Nat Prod Commun 2014;9:337-40.

17. Kim KM, Jang WG. Zaluzanin C (ZC) induces osteoblast differentiation through regulating of osteogenic genes expressions in early stage of differentiation. Bioorg Med Chem Lett 2017; 27:4789-93.

18. Lee EW, Kim T, Kim HS, Park YM, Kim SH, Im MH, et al. Antioxidant and $\alpha$-glucosidase inhibitory effects of ethanolic extract of Ainsliaea acerifolia and organic solvent-soluble fractions. Korean J Food Preserv 2015;22:275-80.

19. Rizzatti V, Boschi F, Pedrotti M, Zoico E, Sbarbati A, Zamboni M. Lipid droplets characterization in adipocyte differentiated 3T3-L1 cells: size and optical density distribution. Eur J Histochem 2013;57:e24.

20. Kwak SH, Kim TH, Kim YH. Inhibitory effect of natural compounds in differentiation of 3T3-L1 preadipocyte. J Ind Technol 2018;29:51-5.

21. Green H, Kehinde O. An established preadipose cell line and its differentiation in culture. II. Factors affecting the adipose conversion. Cell 1975;5:19-27.

22. Kuri-Harcuch W, Green H. Increasing activity of enzymes on pathway of triacylglycerol synthesis during adipose conversion of 3T3 cells. J Biol Chem 1977;252:2158-60.

23. Moseti D, Regassa A, Kim WK. Molecular regulation of adipogenesis and potential anti-adipogenic bioactive molecules. Int J Mol Sci 2016;17:E124.

24. Pan MH, Tung YC, Yang G, Li S, Ho CT. Molecular mechanisms of the anti-obesity effect of bioactive compounds in tea and coffee. Food Funct 2016;7:4481-91.

25. Cowherd RM, Lyle RE, McGehee RE Jr. Molecular regulation of adipocyte differentiation. Semin Cell Dev Biol 1999;10:3-10.

26. MacDougald OA, Lane MD. Transcriptional regulation of gene expression during adipocyte differentiation. Annu Rev Biochem 1995;64:345-73.

27. Johmura Y. Characterization of novel genes regulating adipocyte differentiation. Yakugaku Zasshi 2007;127:135-42.

28. Thompson GM, Trainor D, Biswas C, LaCerte C, Berger JP, Kelly LJ. A high-capacity assay for PPARgamma ligand regulation of endogenous aP2 expression in 3T3-L1 cells. Anal Biochem 2004;330:21-8.

29. Takahashi N, Kawada T, Goto T, Yamamoto T, Taimatsu A, Matsui N, et al. Dual action of isoprenols from herbal medicines on both PPARgamma and PPARalpha in 3T3-L1 adipocytes and HepG2 hepatocytes. FEBS Lett 2002;514:315-22.

30. Rosen ED, Hsu CH, Wang X, Sakai S, Freeman MW, Gonzalez FJ, et al. C/EBPalpha induces adipogenesis through PPARgamma: a unified pathway. Genes Dev 2002;16:22-6.

31.El-Jack AK, Hamm JK, Pilch PF, Farmer SR. Reconstitution of insulin-sensitive glucose transport in fibroblasts requires expression of both PPARgamma and C/EBPalpha. J Biol Chem 1999;274:7946-51.

32. Finck BN. Targeting metabolism, insulin resistance, and diabetes to treat nonalcoholic steatohepatitis. Diabetes 2018;67: 2485-93.

33. Jeong GH, Kim TH. Characterization of anti-advanced glycation end products (AGEs) and radical scavenging constituents from Ainsliaea acerifolia. J Korean Soc Food Sci Nutr 2017; 46:759-64. 